\title{
Postmortem findings in Magellanic penguins (Spheniscus magellanicus) caught in a drift gillnet
}

\author{
Ana Carolina Ewbank ${ }^{1 * \dagger}$ (D), Carlos Sacristán ${ }^{1 \dagger}$, Samira Costa-Silva ${ }^{2}$, Marzia Antonelli ${ }^{2}$, Janaina R. Lorenço ${ }^{2}$, \\ Guilherme A. Nogueira², Mariana B. Ebert ${ }^{3}$, Cristiane K. M. Kolesnikovas ${ }^{2}$ and José Luiz Catão-Dias ${ }^{1}$
}

\begin{abstract}
Background: Penguin interaction with gillnets has been extensively reported in the Atlantic and Pacific Oceans, and is considered a major conservation threat. Among penguin species, Magellanic penguins (Spheniscus magellanicus) are currently considered of great concern, particularly in Brazil, where they are highly susceptible to gillnet bycatch. Nevertheless, information about drowning-associated microscopic findings in penguins is limited.

Results: We describe the anatomopathological findings of 20 Magellanic penguins that drowned after getting entangled in a drift gillnet while wintering along the Brazilian shelf and washed ashore still enmeshed in Santa Catarina, Brazil. All 20 birds (19 juveniles and 1 adult; 18 females and 2 males) were in good body condition. Major gross findings were abrasion, bruising, and local erythema and edema of the wings, multiorgan congestion, jugular vein engorgement, pulmonary edema and hemorrhage, splenomegaly and hepatomegaly, fluid in the trachea, serous bloody fluid in the lungs, gastrointestinal parasites (nematodes, cestodes and trematodes), and debris in the stomach. The most common histopathological findings were cerebral and pulmonary congestion, pulmonary edema, splenic histiocytosis, lymphoid splenic hyperplasia, acute splenitis, extramedullary hepatic hematopoiesis, and parasitic enteritis. Although unspecific, the observed multiorgan congestion and pulmonary edema are consistent with previous reports of drowning in birds and may be indicative of this process.

Conclusions: Drowning may be a challenging diagnosis (e.g., carcass decomposition, predation), but must be considered as a differential in all beach-cast seabird postmortem examinations. To the authors' knowledge this is the largest anatomopathological study based on microscopic examination in drowned penguins.
\end{abstract}

Keywords: Brazil, Bycatch, Drowning, Fisheries, Histopathology, Seabirds, Stranding

\section{Background}

Bycatch refers to incidental mortality and/or injury in fishing gear of individuals of target species that are discarded ("discarded catch") and of nontarget species ("incidental

\footnotetext{
* Correspondence: carolewbank@yahoo.com.br

${ }^{\dagger}$ Ana Carolina Ewbank and Carlos Sacristán contributed equally to this work. 'Laboratory of Wildlife Comparative Pathology, Department of Pathology, School of Veterinary Medicine and Animal Sciences, University of São Paulo, São Paulo, SP 05508-270, Brazil

Full list of author information is available at the end of the article
}

catch") [1-3]. Seabird bycatch mortality, in both commercial and artisanal fishing operations, is recognized as a major threat to the conservation of seabird species worldwide [4-6]. Penguin bycatch has been largely reported in the Atlantic and Pacific Oceans, in 14 of the 18 penguin species [7], and is a threat to penguin conservation. In South America, gillnet bycatch of Magellanic penguins (Spheniscus magellanicus) has been reported in Brazil [811], Argentina [12], Chile [13, 14] and Peru [15], while

C C The Author(s). 2020 Open Access This article is licensed under a Creative Commons Attribution 4.0 International License, which permits use, sharing, adaptation, distribution and reproduction in any medium or format, as long as you give appropriate credit to the original author(s) and the source, provide a link to the Creative Commons licence, and indicate if changes were made. The images or other third party material in this article are included in the article's Creative Commons licence, unless indicated otherwise in a credit line to the material. If material is not included in the article's Creative Commons licence and your intended use is not permitted by statutory regulation or exceeds the permitted use, you will need to obtain permission directly from the copyright holder. To view a copy of this licence, visit http://creativecommons.org/licenses/by/4.0/. The Creative Commons Public Domain Dedication waiver (http://creativecommons.org/publicdomain/zero/1.0/) applies to the data made available in this article, unless otherwise stated in a credit line to the data. 
bycatch by trawl fisheries has been reported in Argentina [16-19]. In addition, Magellanic penguins presenting postmortem signs of fishing interaction or entanglement in fishing gear have been reported in Chile [20] and Brazil $[21,22]$.

Magellanic penguins are widely distributed along the southern coast of South America [23]. With an estimated global population between 1.1 and 1.6 million pairs, this species is currently listed as 'near threatened' due to marine pollution, fisheries bycatch and competition for food resources, habitat degradation, diseases, and climate changes $[23,24]$. On the Atlantic coast, the species breeds from Northern Patagonia (Complejo Islote lobos, $\left.41^{\circ} 26^{\prime} \mathrm{S}, 65^{\circ} 01^{\prime} \mathrm{W}\right)$ to Tierra del Fuego $\left(54^{\circ} 54^{\prime} \mathrm{S}, 6^{\circ} 23^{\prime} \mathrm{W}\right)$, Argentina $[25,26]$. During the non-breeding period (austral autumn and winter), animals from colonies at the Atlantic/Argentinean coast migrate through the continental shelf off the coast of northern Argentina, Uruguay, and southern Brazil following the Argentine anchovy (Engraulis anchoita), their diet's main food item in the wintering grounds $[10,27]$. Bycatch has been suggested as a significant source of mortality for this species during migration [9]. Magellanic penguins are considered highly susceptible to gillnet bycatch in Brazil, Uruguay, Argentina and Chile [7].

Drowning is defined as death following respiratory impairment consequent of submersion or immersion (partial submersion) in liquid [28, 29]. There are no pathognomonic postmortem lesions for the diagnosis of drowning in humans and in other mammals [30]. The diagnosis of death by drowning in seabirds is particularly challenging, not only due to the difficulty in differentiating drowning and postmortem submersion [31], but also because drowning studies in seabirds are scarce, and have been primarily based on beach-cast carcasses presenting unspecific external lesions compatible with alleged entanglement in fishing nets (e.g., abrasions, subcutaneous bruising) $[14,20]$, on the presence of water in the lungs and/or air sacs [32-35], or solely based on visual observation of the drowned bird entangled in fishing gear [36]. Furthermore, these studies are usually performed in beach-cast carcasses that have been subjected to a variety of postmortem challenges (e.g., predation, weather exposure, amount of time the carcass remained adrift, and autolysis).

Herein we describe and discuss the gross and microscopic findings of 20 Magellanic penguins that drowned after getting entangled in a drift gillnet in southern Brazil, and discuss the potential ecological effects of bycatch on Magellanic penguin conservation. Additionally, we briefly suggest data collection measures that would greatly contribute to the study of bycatch and drowningassociated lesions in seabirds.

\section{Results}

\section{Macroscopic findings}

All 20 birds - 19 juveniles (18 females and 1 male) and 1 adult (female) were in good body condition. Major macroscopic findings were abrasion, bruising, and local erythema and edema of the wings $(10 / 20 ; 50 \%)$, congested lungs $(20 / 20 ; 100 \%)$, brain $(20 / 20 ; 100 \%)$, spleen (7/20; 35\%), heart $(6 / 20 ; 30 \%)$, kidneys $(4 / 20 ; 20 \%)$, liver $(1 / 20 ; 5 \%)$, and pulmonary edema $(20 / 20 ; 100 \%)$ (presence of foamy serosanguineous fluid when the lungs were cut, severely and diffusely increased lung volume and presence of a gelatinous and sanguineous layer of approximately $2 \mathrm{~mm}$ covering the dorsal lung surface), splenomegaly $(11 / 20 ; 55 \%)$ and hepatomegaly $(4 / 20$; 20\%) (Fig. 1). Jugular vein engorgement (bilateral) was not systematically recorded but was observed in at least ten animals (10/20; 50\%) (Fig. 1).

Gastrointestinal parasitosis was observed in 18 out 20 penguins: nematodes Contracaecum pelagicum in the stomach $(P=80 \%$; MII $=4.6 \pm 2.2$; range $=2-10$ parasites per host], and cestodes Tetrabothrius [Neotetrabothrius] lutzii $[P=55 \%$; $\mathrm{MII}=1$; range $=1$ parasite per host $)$ and trematodes Cardiocephaloides physalis $[P=35 \%$; $\mathrm{MII}=$ $1.8 \pm 1.1$; range $=1-4$ parasites per host $]$ in the intestines. Two birds presented debris in the stomach $(2 / 20$; 10\%): a small nylon fragment and an unidentified piece of plastic. Gross findings are listed in Table 1.

\section{Microscopic findings}

The following mild to moderate histopathological findings were most commonly observed: cerebral and meningeal congestion (19/20; 95\%), pulmonary congestion $(8 / 20 ; 40 \%)$, diffuse acute granulocytic pneumonia (7/20; $35 \%)$, pulmonary edema $(7 / 20 ; 35 \%)$, cardiac congestion $(3 / 20 ; 15 \%)$, splenic histiocytosis $(7 / 20 ; 35 \%)$, lymphoid splenic hyperplasia $(11 / 20 ; 55 \%)$, acute diffuse splenitis (7/20; 35\%), lymphoplasmacytic portal hepatitis (5/20; $25 \%)$, hepatic extramedullary hematopoiesis (7/20;35\%), and renal congestion $(8 / 20 ; 40 \%)$. We also observed parasitic enteritis and typhlitis (13/20; 65\% and 4/20; $20 \%$, respectively). All histopathological findings are listed in Table 1 and the most significant ones are shown in Fig. 2.

Finally, our necropsy findings did not indicate the presence of metabolic or neoplastic conditions; therefore, no further diagnostic analysis were pursued.

\section{Discussion}

This study describes the gross and histopathological findings in 20 well-preserved stranded dead Magellanic penguins washed ashore still enmeshed in an artisanal triple-layered drift gillnet (mesh size $35-45 \mathrm{~mm}$ ). Based on our findings, we consider entanglement and subsequent drowning as the most likely explanation for the 


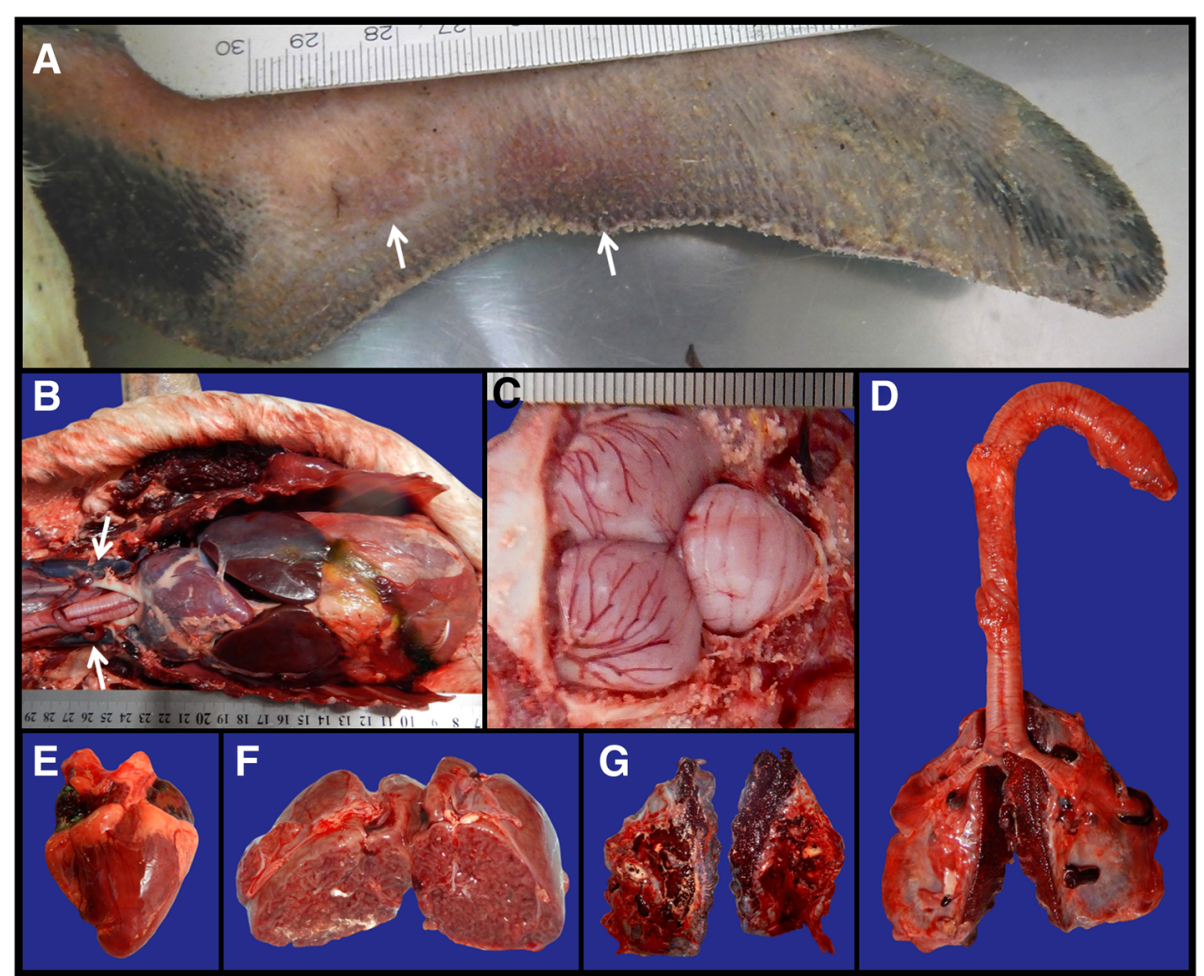

Fig. 1 Macroscopic findings on the studied Magellanic penguins (Spheniscus magellanicus). All animals presented congestion in at least one system, likely caused by decreased cardiac output due to increased vascular resistance in the lungs, cardiac anoxia and acidosis. a Left wing (ventral view): edema and bruising (white arrows). b Coelomic cavity: generalized congestion and hepatomegaly, and bilateral jugular vein engorgement (white arrows). c Brain: congestion and edema. d Trachea, bronchi and lungs: congestion, and pulmonary and serosal edema. e Heart: normal fat deposits, congestion (especially in the left and right atria). $\mathbf{f}$ Cranial kidney lobe (transversal section): congestion. $\mathbf{g}$ Lungs: pulmonary congestion and edema

presence of these penguins in the net, once other possibilities (e.g., the animals drifted into a net when already dead) are considered remote. We hypothesize the drift gillnet was likely discarded by the fishermen because the animals were severely entangled (see Fig. 3) and, most of all, to avoid any legal responsibilities. Drift gillnets are highly efficient artisanal fishing apparatus projected for stationary use in coastal waters [37]. However, they act as a wall that ends up capturing non-target species as well (e.g., sea turtles, cetaceans, seabirds and non commercial fish species) [37-39]. As air-breathing pursuit divers, penguins are likely to interact with gillnets when foraging, transiting or resting on the surface [13-15]. Their potential impact in regards to bycatch may not be comparable with fishing nets used by commercial fisheries (e.g., longer and used offshore); however, gillnets are still a threat to penguins. Previous reports evidenced the gillnet bycatch of a large number of penguins in southern Brazil [8-11]; nonetheless, these studies did not perform complete postmortem examinations.

Aspiration of saltwater, which is 3 to 4 times more hypertonic than blood, leads to the development of acute alveolar edema as a result of protein-rich fluid drainage from the intravascular space into the pulmonary alveoli, disrupting the integrity of the alveolar-capillary membrane and increasing its permeability, exacerbating fluid, plasma, and electrolyte shifts, and causing dilution and washout of surfactant $[28,29,40]$. When fluid enters the airways, it usually results in bronchospasm, leading to an increase in relative intrapulmonary shunting [28, 41]. These physiopathological events combined with the consequent decreased lung compliance, atelectasis, and ventilation-perfusion mismatch result in hypoxemia, and ultimately death $[28,29,41]$. Meanwhile, the acute hypoxemia and stress response release high levels of catecholamine, leading to transient tachycardia and hypertension [42]. Hypoxemia may also reduce myocardial contractility and along with acidosis increase the risk for arrhythmias (e.g., ventricular tachycardia, fibrillation, and asystole) and cardiogenic shock [42]. Hypoxia intensifies as the arterial oxygen tension decreases, leading to bradycardia and vasoconstriction in 'nonvital' organs to promote blood flow to the heart and central nervous system and reduce myocardial oxygen consumption, in an attempt to prolong hypoxia tolerance. Additionally, during this process, endothelial cells are activated, releasing inflammatory mediators that contribute to the development of a systemic inflammatory 
Table 1 Number of Magellanic penguins (Spheniscus magellanicus) presenting gross pathological and histological findings listed by system and prevalence $(P)$

\begin{tabular}{ll}
\hline System & Macroscopic findings $(\boldsymbol{n}=20)$ \\
\hline $\begin{array}{l}\text { System } \\
\text { Respiratory }\end{array}$ & Cardiac congestion \\
Cystem & $\begin{array}{l}\text { Dilated atria } \\
\text { Jugular vein engorgement (bilateral) }\end{array}$ \\
& Pulmonary edema \\
& Pulmonary congestion \\
& Pulmonary hemorrhage \\
& Tracheal hemorrhage \\
& Tracheal blood cloth \\
Fracthy fluid in the trachea \\
\end{tabular}

Hepatobiliary Hepatomegaly

$\begin{array}{lll}\mathrm{P} & \text { Microscopic findings }(\boldsymbol{n}=20) & \mathrm{P} \\ 30 \%(6) & \text { Cardiac congestion } & 15 \% \\ & & (3)\end{array}$

$5 \%(1)$

$5 \%(1)$

$50 \%(10)$

100\% Pneumonia 55\%

(20) (11)

$100 \% \quad$ - Mild to moderate acute diffuse granulocytic pneumonia $35 \%$

(20)

$20 \%(4) \quad$ - Acute diffuse pneumonia $\quad 20 \%$

5\% (1) Mild to moderate pulmonary congestion $\quad 40 \%$

5\% (1) Mild to moderate pulmonary edema $35 \%$

5\% (1) Mild tracheal congestion $\quad 5 \%(1)$

Mild to moderate tracheal edema $\quad 5 \%(1)$

Mild segmented mononuclear tracheitis $\quad 5 \%(1)$

Distension of the tracheal lymphoid tissue $\quad 5 \%(1)$

Mild extension of the tracheal lamina propria $\quad 5 \%(1)$

$75 \%$ (15) Acute diffuse mild esophagitis 15\%

(3)

$55 \%$ (11) Mild to moderate multifocal coalescent esophageal $\quad 10 \%$ microabscesses

(2)

40\% (8) Mild enteric congestion $\quad 5 \%$ (1)

25\% (5) Mild to moderate acute diffuse granulocytic $\quad 5 \%$ (1) proventricular infiltrate

15\% (3) Mild to moderate acute diffuse proventriculitis $\quad 5 \%$ (1)

10\% (2) Proventricular ulcer $5 \%$ (1)

Mild to moderate acute diffuse ventricular infiltrate $\quad 5 \%(1)$

Parasitic enteritis 65\%

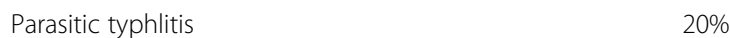

Coccidiosis $\quad 5 \%(1)$

20\% (4) Hepatic extramedullary hematopoiesis $35 \%$

(7)

Hepatic congestion

5\% (1) Mild to moderate lymphoplasmacytic hepatitis

Mild mixed multifocal hepatitis

Mild predominantly mononuclear periportal hepatitis with $5 \%$ (1) rare granulocytes

Mild perivascular lymphocytic hepatitis $\quad 5 \%(1)$

Granulocytic hepatitis $\quad 5 \%$ (1)

Mild to moderate diffuse hepatic congestion $\quad 15 \%$

Hepatic duct hyperplasia $\quad 10 \%$

Hepatic hemosiderosis $\quad 10 \%$ 
Table 1 Number of Magellanic penguins (Spheniscus magellanicus) presenting gross pathological and histological findings listed by system and prevalence (P) (Continued)

\begin{tabular}{|c|c|c|c|c|}
\hline System & Macroscopic findings $(\boldsymbol{n}=20)$ & $P$ & Microscopic findings $(\boldsymbol{n}=20)$ & $\mathrm{P}$ \\
\hline & & & & (2) \\
\hline & & & Mild to moderate diffuse vacuolar hepatic degeneration & $5 \%(1)$ \\
\hline \multirow[t]{3}{*}{$\begin{array}{l}\text { Central Nervous } \\
\text { System }\end{array}$} & Brain congestion & $\begin{array}{l}100 \% \\
(20)\end{array}$ & Cerebral congestion & $\begin{array}{l}95 \% \\
(19)\end{array}$ \\
\hline & Meningeal congestion & $25 \%(5)$ & & \\
\hline & Skull cap congestion & $10 \%(2)$ & & \\
\hline \multirow[t]{8}{*}{ Lymphoid System } & Splenomegaly & $55 \%(11)$ & Mild to moderate lymphoid splenic hyperplasia & $\begin{array}{l}55 \% \\
(11)\end{array}$ \\
\hline & Splenic congestion & $35 \%(7)$ & Mild to moderate splenic histiocytosis & $\begin{array}{l}35 \% \\
(7)\end{array}$ \\
\hline & Congestion of the bursa of Fabricius & $5 \%(1)$ & Mild to moderate acute diffuse splenitis & $\begin{array}{l}35 \% \\
(7)\end{array}$ \\
\hline & & & Mild splenic congestion & $\begin{array}{l}10 \% \\
(2)\end{array}$ \\
\hline & & & Mild splenic lymphocytolysis & $\begin{array}{l}10 \% \\
(2)\end{array}$ \\
\hline & & & Moderate splenic lymphoid proliferation & $5 \%(1)$ \\
\hline & & & $\begin{array}{l}\text { Hyperplasia of the splenic germinative centre with } \\
\text { arteriole displacement }\end{array}$ & $5 \%(1)$ \\
\hline & & & Necrosis of the splenic germinative centre & $5 \%(1)$ \\
\hline \multirow[t]{3}{*}{$\begin{array}{l}\text { Genitourinary } \\
\text { System }\end{array}$} & Renal congestion & $20 \%(4)$ & Renal congestion & $\begin{array}{l}40 \% \\
(8)\end{array}$ \\
\hline & & & Interstitial nephritis & $\begin{array}{l}10 \% \\
(2)\end{array}$ \\
\hline & & & Histiocytic lymphoplasmacytic multifocal nephritis & $5 \%(1)$ \\
\hline $\begin{array}{l}\text { Musculoskeletal } \\
\text { System }\end{array}$ & Bilateral scapulohumeral joint edema & $5 \%(1)$ & $N A^{a}$ & NA \\
\hline $\begin{array}{l}\text { Integumentary } \\
\text { System }\end{array}$ & $\begin{array}{l}\text { Abrasion, bruising, and local erythema and } \\
\text { edema of the wings }\end{array}$ & $\begin{array}{l}50 \%(10 / \\
20)\end{array}$ & $N A^{a}$ & \\
\hline \multirow[t]{4}{*}{$\begin{array}{l}\text { Miscellaneous } \\
\text { findings }\end{array}$} & Generalized hemoglobin impregnation & $3 / 20$ & Pancreatic congestion & $\begin{array}{l}10 \% \\
(2)\end{array}$ \\
\hline & Caseous material in the mesentery & $5 \%(1)$ & Harderian gland congestion & $5 \%(1)$ \\
\hline & & & Thyroid congestion & $5 \%(1)$ \\
\hline & & & Parathyroid congestion & $5 \%(1)$ \\
\hline
\end{tabular}

${ }^{\mathrm{a} N A}$ : not available

response syndrome often accompanied by peripheral vasoplegia and capillary leakage [28].

The congestion of multiple organs (upon microscopy, more often seen in the brain, lungs and kidneys) and the pulmonary edema observed in both macroscopic and microscopic examinations of our cases ratify the findings of Vanstreels et al. [22] and Simpson and Fisher [43] in seabirds, and were strongly suggestive of drowning. Generalized congestion was likely caused by increased pulmonary vascular resistance, cardiac dysfunction secondary to the extent and duration of hypoxia, and changes in acid-base balance (acidosis), that lead to decreased cardiac output [22, 28, 42], whereas pulmonary edema was caused by aspiration of saltwater and/or increased pulmonary venous pressure $[28,29]$. To the authors' knowledge, this is the largest study based on gross and microscopic pathology in penguins. Only recently, Vanstreels et al. [22] reported the gross and microscopic findings of two Magellanic penguins that drowned and died after getting entangled in gillnet in southeastern Brazil: one in a floating $(3 \mathrm{~m})$ and the other in a bottom gillnet $(12 \mathrm{~m})$. Some of the previous studies with seabirds have relied solely on gross findings [43] or on histopathological examination of samples partially compromised by freezing [20, 32] to diagnose drowning, when microscopic examination is essential for a more accurate diagnosis. 


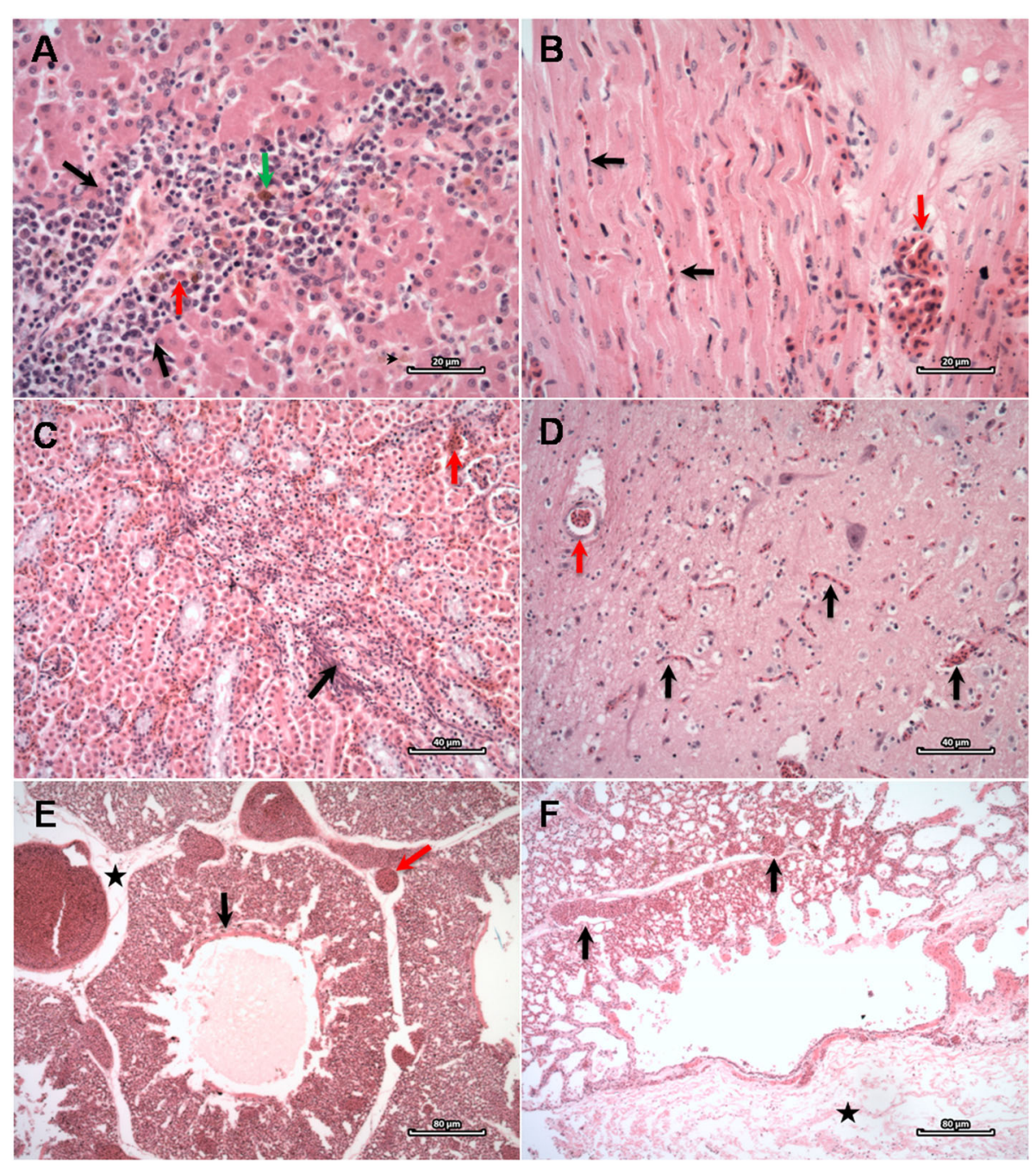

Fig. 2 Microscopic findings on the studied Magellanic penguins (Spheniscus magellanicus). a Liver: hepatitis (red arrow), hemosiderin inside Kupffer cells (green arrow) and hepatocytes (black arrow head), extramedullary hematopoiesis (black arrows). HE. Scale bar $=20 \mu m$ (b) Heart: diffuse congestion (black arrows), markedly congested vessel (red arrow). HE. Scale bar $=20$ um. c Kidney: diffuse congestion (red arrow), multifocal interstitial nephritis (black arrow). HE. Scale bar $=40 \mu \mathrm{m}$. d Brain: diffuse congestion (black arrows) and inside arteriole (red arrow). HE. Scale bar $=40 \mu \mathrm{m}$. e Lung: congestion and edema, proteinaceous material in parabronchial lumen (black arrow), stretched interparabronchial septa due to edema (asterisk) and markedly congested vessels, including septal arterioles (red arrow). HE. Scale bar $=80 \mu \mathrm{m}$. f Lung: diffuse congestion (black arrows), markedly stretched visceral pleura (asterisk) due to edema. HE. Scale bar $=80 \mu \mathrm{m}$

Other significant gross and/or microscopic findings, useful to evaluate the health of migrating penguins, but likely not related with drowning, were pneumonia, splenomegaly and hepatomegaly, splenic histiocytosis and lymphoid hyperplasia, hepatic extramedullary hematopoiesis, and gastrointestinal parasitosis (associated with enteritis and typhlitis). Even though the pneumonia findings were characterized as acute, the drowning event was fatal and could not have lasted long enough to promote such condition, in spite of the lung inflammation seen in near-drowned cases with seawater inhalation [44]. Granulocytic pneumonia was previously described in two drowned penguins [22]. We consider that the etiology of the pneumonia seen in our study was not related to the drowning event and that its causes remain unknown. The observed splenomegaly and hepatomegaly could be due to a combination of one or more of the following factors: congestion, increased antibody production caused by parasite infection/infestation [45], and immunological challenges (i.e., marine pollution and infectious agents) [46-48]. The observed splenic histiocytosis and lymphoid hyperplasia could also have been caused by parasite infection/infestation, and immunological challenges - commonly faced by this species during migration. Hepatic extramedullary hematopoiesis - the formation and development of blood cells in organs other than the medullary spaces of the bone marrow [49], was also observed in the liver of five 


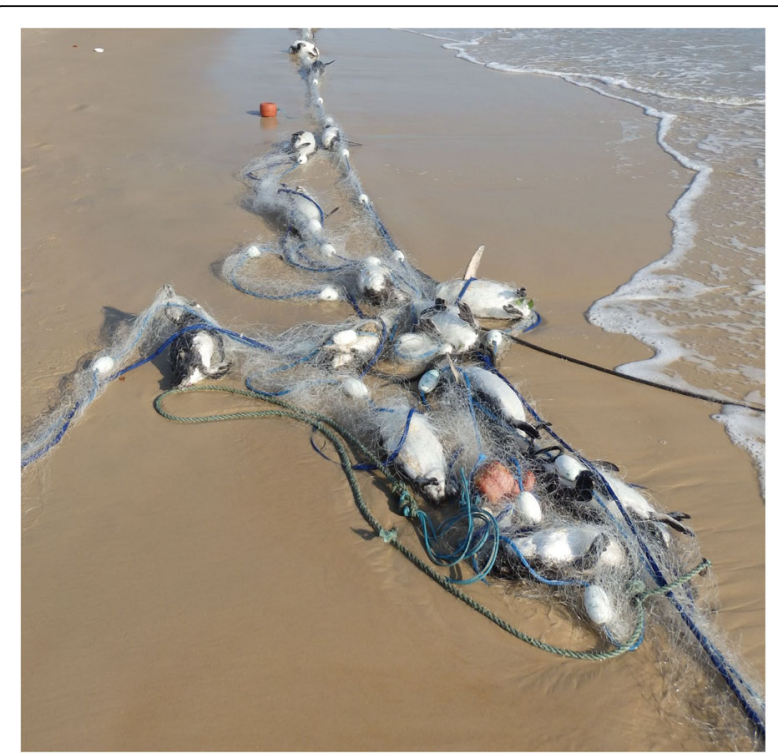

Fig. 3 Drowned Magellanic penguins (Spheniscus magellanicus). Twenty birds were washed ashore still entangled in an artisanal triple-layered drift gillnet in Santa Catarina state, Brazil

penguins. This finding may be associated with immune response following infection and exercise, or with increased erythropoietin production during hypoxia [49, 50]. We believe the immune response to parasite infection and physical challenge required by migration was possibly the causative factor, once these birds went through an acute hypoxic event (drowning) that was not long enough to increase erythropoietin production. Gastric parasitosis caused by the nematode C. pelagicum, and mild to severe multifocal to diffuse intestinal parasitosis caused by the cestode T. (Neotetrabothrius) lutzi and the trematode $C$. physalis were also observed. The described parasite species likely caused the parasitic enteritis and typhlitis reported here, and are commonly reported in Magellanic penguins; however, most of these studies are primarily taxonomic and only a few have related their presence to diseases in penguins [51-53]. Although parasitosis may strongly influence the physical condition of their hosts, and therefore, increase their vulnerability [54], all these animals were in good body condition. The impact of parasites on Magellanic penguins remains unclear, requiring further extensive pathological studies to clarify parasitic influence on this species.

All birds had empty stomachs upon necropsy, with the exception of two juveniles $(2 / 20 ; 10 \%)$ that presented a small amount of marine debris in their stomachs (Table $1)$. The empty stomachs could be explained by the following hypothesis: (1) entanglement occurred as soon as the penguins started interacting with the gillnet, leaving them no time to ingest any prey or (2) the birds got entangled while transiting or resting at sea. Empty stomachs are often described in drowned seabirds [14]. Studies on Magellanic penguin carcasses washed ashore in southern and southeastern Brazil reported that, respectively, $14.86 \%(26 / 175)$ [55] and 80\% (115/144) [21] of the individuals presented materials of anthropogenic origin in the stomach (marine debris). Marine debris ingestion by Magellanic penguins poses a threat for the species' conservation throughout its distribution and has been widely reported in Brazil [55-59]. The discussed hypothesis for such findings include juvenile inexperience, hunger, and difficulty in finding food (e.g., reduced diving capacity due to poor physical condition) $[55,60]$. However, both birds were in good body condition and likely ingested the debris involuntarily, either by mistake or in the body of a prey [55].

The majority of the Magellanic penguins evaluated in this study were juveniles, and similarly to the only adult, were in good body condition - suggesting that the observed histopathological processes were not compromising the birds' ability to successfully feed and meet their daily energy requirements. Most of the juveniles found ashore in Brazil are emaciated or cachectic [57, 61]; thus, our microscopic study of apparently healthy wintering individuals provides valuable anatomopathological information regarding this poorly studied phase of their life cycle. The age groups described in previous reports of penguin bycatch in Brazil are contradictory. Vanstreels et al. [22] and the present study reported mostly juveniles, respectively, 100 and 95\%, while Cardoso et al. [9], Marques et al., 2018 [10], and Fogliarini et al., 2019 [11] identified mostly adults (respectively, 81, 77 and 53\%).

We found a higher number of females than males in this study, likely as a consequence of sexual dimorphismrelated mechanisms that determine sexual differences in spatial domains $[62,63]$ and habitat segregation between Magellanic penguin sexes during wintering dispersal. Age and sex parameters are important factors in the assessment of bycatch impacts [62]. Sex ratio variation in wild populations has important consequences for population dynamics by compromising population viability [63]. The age- and sex-related data of Magellanic penguin bycatch in wintering areas is still limited; however, long-term situations affecting both juveniles and females (as seen in this study) could potentially reduce population productivity.

\section{Conclusions}

To the authors' knowledge, this is the largest anatomopathological study based on microscopic examination in drowned Magellanic penguins. Drowning must be considered a differential diagnosis in all beach-cast seabird postmortem examinations, especially in those presenting generalized congestion and edema. This diagnosis should be established based on gross and microscopic 
findings, preferably associated with recovery history (when present), and must be promptly and consistently performed by trained personnel, and fully registered through photo identification to further characterize the physiopathology and postmortem findings of drowning. Finally, in order to characterize seabird bycatch events, including in Magellanic penguins, and understand the impact of fishing interaction on their conservation, future studies need to identify the age, sex and stage of the life cycle in which the birds were at the time of the event (e.g., breeding season, migration), and interpret such findings based on the species' conservation status, population size, demography, dispersal at sea, and estimates of bycatch mortality throughout the species' range.

\section{Methods}

\section{Samples}

On August 17th 2016, 20 Magellanic penguins that drowned after being caught in an artisanal triple-layered drift gillnet (Fig. 3) during wintering were washed ashore, still entangled, at Praia dos Ingleses $\left(27^{\circ} 26^{\prime} \mathrm{S}, 48^{\circ} 23^{\prime} \mathrm{W}\right)$ in Florianópolis county, Santa Catarina state, southern Brazil. The carcasses were immediately collected and necropsied by Associação R3 Animal/Coastal Monitoring Program - Santos Basin (Projeto de monitoramento de Praias da Bacia de Santos - PMP-BS). The necropsy regimen was conducted within the following time frame: five carcasses in $24 \mathrm{~h}$, ten in $48 \mathrm{~h}$ and five in $72 \mathrm{~h}$. Carcasses not necropsied on the same day were kept refrigerated until necropsy. All carcasses appeared very fresh and had no signs of predation. Necropsies were performed in fresh or refrigerated carcasses within $72 \mathrm{~h}$ following their discovery, according with previously established techniques $[64,65]$. Upon necropsy, body condition was determined based on palpation and posterior visualization of pectoral muscles and the keel [48]. Age was determined based on plumage characteristics [66] and sexing was established upon visualization of the gonads [48]. All samples used in this study were collected in full compliance with specific federal permits issued by the Brazilian Ministry of Environment and approved by the Biodiversity Information and Authorization System (SISBIO 20825-8) and by the Brazilian Institute of Environment and Renewable Natural Resources - IBAMA (ABIO 640/2015). Because this study involved dead birds, it did not require official or institutional ethical approval.

\section{Histopathological study}

Collected tissue samples (heart, aorta, trachea, lungs, brain, thyroid, parathyroid, tongue, esophagus, proventriculus, intestines, liver, spleen, gall bladder, pancreas, kidneys, skeletal muscle, bursa of Fabricius, Harderian gland, uropygeal gland and supraorbital gland) were placed in $10 \%$ buffered formalin. Formalin-fixed tissues were routinely processed, sectioned at $5 \mu \mathrm{m}$, stained with hematoxylin and eosin, and examined under light microscopy.

\section{Parasitological identification}

Parasite samples were recovered from the gastrointestinal tract of 18 out of 20 penguins, and prepared for morphological identification according with the group (nematode, trematode or cestode) and following standard protocols [67], and identified based on measurements and morphological observations under light microscopy on a computerized system of image analysis (Qwin Lite 3.1, Leica Microsystems), according to specific literature $[52,68-70]$. The prevalence $(\mathrm{P})$, mean intensity of infection (MII) and standard deviation were calculated according to Bush et al. [71] in the program Bioestat 5.3.

\section{Acknowledgements}

We thank the staff of the Associação R3 Animal, Sândara Sguario and Juliana Marigo for their technical assistance.

\section{Authors' contributions}

Conceived and designed the study: ACE, JLCD. Performed the experiments: ACE, CS, SC-S, MA, JRL. Analyzed the data: ACE, CS, SC-S, MA, JRL, GAN, MBE, CKMK, JLCD. Wrote the paper: ACE and CS. Reviewed the paper: ACE, CS, SC$S, M A, J R L, G A N, M B E, C K M K, J L C D$. All authors have read and approved the manuscript and its submission.

\section{Funding}

This study was funded by The Brazilian National Council for Scientific and Technological Development (CNPq), the Coordination for the Improvement of Higher Education Personnel (CAPES), the São Paulo Research Foundation (FAPESP), and the Coastal Monitoring Program - Santos Basin (PMP-BS), required by the Brazilian Institute of the Environment and Renewable Natural Resources (IBAMA) of the Brazilian Ministry of Environment for the environmental licensing process of the oil production and transport by Petrobras at the pre-salt province $\left(25^{\circ} 05^{\prime} \mathrm{S} 42^{\circ} 35^{\prime} \mathrm{W}\right.$ to $\left.25^{\circ} 55^{\prime} \mathrm{S} 43^{\circ} 34^{\prime} \mathrm{W}\right)$, between $2100 \mathrm{~m}$ and $2300 \mathrm{~m}$ isobaths. The study design, collection, analysis and interpretation of data, as well as the article elaboration and submission, were solely performed by the authors, without any involvement from the funders. Ana Carolina Ewbank and Carlos Sacristán are recipients of PhD and postdoctoral fellowship by the FAPESP (FAPESP 2016/20956-0 and FAPESP 2018/ 25069-7, respectively). José Luiz Catão-Dias is the recipient of a professorship from CNPq (304999-18).

\section{Availability of data and materials}

The datasets of the current study are available from the corresponding author upon request.

\section{Ethics approval and consent to participate}

The samples used in this study were collected in full compliance with an specific federal permit issued by the Brazilian Ministry of Environment and approved by the Brazilian Institute of Environment and Renewable Natural Resources - IBAMA (ABIO 640/2015). Because this study involved dead birds, it did not require official or institutional ethical approval.

\section{Consent for publication}

Not applicable.

\section{Competing interests}

The authors declare that they have no competing interests.

\section{Author details}

${ }^{1}$ Laboratory of Wildlife Comparative Pathology, Department of Pathology, School of Veterinary Medicine and Animal Sciences, University of São Paulo, São Paulo, SP 05508-270, Brazil. ²Associação R3 Animal, Florianópolis, SC 
88061-500, Brazil. ${ }^{3}$ Laboratory of Wildlife Parasitology (LAPAS), Parasitology Department, Biosciences Institute, São Paulo State University (UNESP), Botucatu, SP 18618-000, Brazil.

Received: 20 November 2019 Accepted: 10 May 2020

Published online: 24 May 2020

\section{References}

1. Alverson DL, Freeberg MH, Pope JG, Murawski SA. A global assessment of fisheries bycatch and discards. FAO fisheries technical paper. No.339. Rome: FAO; 1994.

2. Lewison RL, Soykan CU, Franklin J. Mapping the bycatch seascape: multispecies and multi-scale spatial patterns of fisheries bycatch. Ecol Appl. 2009;19:920-30.

3. Reeves RR, McClellan K, Werner TB. Marine mammal bycatch in gillnet and other entangling net fisheries, 1990 to 2011. Endanger Species Res. 2013;20: 71-97.

4. Žydelis R, Bellebaum J, Österblom H, Vetemaa M, Schirmeister B, Stipniece $A$, et al. Bycatch in gillnet fisheries - an overlooked threat to waterbird populations. Biol Conserv. 2009;142:1269-81.

5. Suazo CG, Cabezas LA, Moreno CA, Arata JA, Luna Jorquera G, Simeone A, et al. Seabird bycatch in Chile: a synthesis of its impacts, and a review of strategies to contribute to the reduction of a global phenomenon. Pac Seabirds. 2014:41:1-12

6. Croxall JP, Butchart SHM, Lascelles BEN, Stattersfield AJ, Sullivan B, Symes A, et al. Seabird conservation status, threats and priority actions: a global assessment. Bird Conserv Int. 2012;22:1-34.

7. Crawford R, Ellenberg U, Frere E, Hagen C, Baird K, Brewin P, et al. Tangled and drowned: a global review of penguin bycatch in fisheries. Endanger Species Res. 2017;34:373-96.

8. Vasconcellos M, Haimovici M, Ramos K. Pesca de emalhe demersal no sul do Brasil: evolução, conflitos e (des) ordenamento. In: Haimovici M, Andriguetto-Filho JM, Sunye PS, editors. A Pesca marinha e estuarina no Brasil: estudos de Caso multidisciplinares. Rio Grande: Editora da FURG; 2014. p. 29-40.

9. Cardoso LG, Bugoni L, Mancini PL, Haimovici M. Gillnet fisheries as a majo mortality factor of Magellanic penguins in wintering areas. Mar Pollut Bull. 2011;62:840-4

10. Marques FP, Cardoso LG, Haimovici M, Bugoni L. Trophic ecology of Magellanic penguins (Spheniscus magellanicus) during the non-breeding period. Estuar Coast Shelf Sci. 2018;210:109-22.

11. Fogliarini CO, Bugoni L, Haimovici M, Secchi ER, Cardoso LG. High mortality of adult female Magellanic penguins by gillnet fisheries in southern Brazil. Aquat Conserv Mar Freshwat Ecosyst. 2019;29:1657-64.

12. Schiavini ACM, Raya Rey A. Aves y mamíferos marinos en Tierra del Fuego. Estado de situación, interacción con actividades humanas y recomendaciones Para su manejo. Puerto Madryn: Fundación Patagonia Natural; 2001.

13. Pütz K, Hiriart-Bertrand L, Simeone A, Riquelme V, Reyes-Arriagada R, Lüthi B. Entanglement and drowning of a Magellanic penguin (Spheniscus magellanicus) in a gill net recorded by a time-depth recorder in southCentral Chile. Waterbirds. 2011;34:121-5.

14. Simeone A, Bernal M, Meza J. Incidental mortality of Humboldt penguins Spheniscus humboldti in gill nets, Central Chile. Mar Ornithol. 1999;27:157-61.

15. Majluf P, Babcock EA, Riveros JC, Schreiber MA, Alderete W. Catch and bycatch of sea birds and marine mammals in the small-scale fishery of Punta San Juan, Peru. Conserv Biol. 2002;16:1333-43.

16. Gandini PA, Frere E, Pettovello AD, Cedrola PV. Interaction between Magellanic penguins and shrimp fisheries in Patagonia, Argentina. Condor. 1999;101:783-9.

17. Tamini LL, Perez JE, Chiaramonte GE, Cappozzo HL. Magellanic penguin Spheniscus magellanicus and fish as bycatch in the cornalito Sorgentinia incisa fishery at Puerto Quequén, Argentina. Atl Seab. 2002;4:109-14

18. González-Zevallos D, Yorio P. Seabird use of discards and incidental captures at the argentine hake trawl fishery in the Golfo san Jorge, Argentina. Mar Ecol Prog Ser. 2006;316:175-83.

19. González-Zevallos D, Yorio P, Caille G. Seabird mortality at trawler warp cables and a proposed mitigation measure: a case of study in Golfo san Jorge, Patagonia, Argentina. Biol Conserv. 2007;136:108-16.
20. Schlatter RP, Paredes E, Ulloa J, Harris J, Romero A, Vasques J, et al. Mortandad de pingüino de Magallanes (Spheniscus magellanicus) en Queule, región de la Araucanía, Chile. Bol Chil Ornitol. 2009;15:78-86.

21. Petry MV, Fonseca VDS. Effects of human activities in the marine environment on seabirds along the coast of Rio Grande do Sul, Brazil. Ornitol Neotrop. 2002;13:137-42.

22. Vanstreels RET, Hurtado R, Ewbank AC, Bertozzi CP, Catão-Dias JL. Lesions associated with drowning in bycaught penguins. Dis Aquat Org. 2016;121: 241-8.

23. BirdLife International. Spheniscus magellanicus. In: The IUCN Red List of Threatened Species 2017. International Union for Conservation of Nature. 2018: e.T22697822A132605485.

24. Trathan PN, García-Borboroglu P, Boersma D, Bost CA, Crawford RJM, Crossin GT, et al. Pollution, habitat loss, fishing, and climate change as critical threats to penguins. Conserv Biol. 2015:29:31-41.

25. Gandini P, Frere E, Boersma PD. Status and conservation of the Magellanic penguin Spheniscus magellanicus in Patagonia, Argentina. Bird Conserv Int. 1996;6:307-16

26. Pozzi LM, Borboroglu PG, Boersma PD, Pascual MA. Population regulation in Magellanic penguins: what determines changes in colony size? PLoS One. 2015;10:e0119002.

27. Silva LA, Siles L, Cardona L, Tavares M, Crespo EA, Gandini PA. Diferencias estacionales en la dieta de individuos juveniles del Pingüino Patagónico (Spheniscus magellanicus) reveladas en base al análisis de isótopos estables en uñas. Hornero. 2015;30:45-54.

28. Hasibeder WR. Drowning. Curr Opin Anesthesiol. 2003;16:139-46.

29. Szpilman D, Bierens JJ, Handley AJ, Orlowski JP. Drowning. N Engl J Med. 2012:366:2102-10.

30. Farrugia A, Ludes B. Diagnostic of drowning in forensic medicine. In: Nuno $\checkmark$, editor. Forensic medicine - from old problems to new challenges. Rijeka: InTech; 2011. p. 53-60.

31. Piette $\mathrm{MH}$, De Letter EA. Drowning: still a difficult autopsy diagnosis. Forensic Sci Int. 2006;163:1-9.

32. Daoust PY, Conboy G, McBurney S, Burgess N. Interactive mortality factors in common loons from maritime Canada. J Wildl Dis. 1998;34:524-31.

33. Hocken AG. Internal organ weights of the blue penguin Eudyptula minor. New Zeal J Zool. 2000;27:299-304.

34. Hocken AG. Necropsy findings in yellow-eyed penguins (Megadyptes antipodes) from Otago, New Zealand. New Zeal J Zool. 2005;32:1-8.

35. Cannell BL, Campbell K, Fitzgerald L, Lewis JA, Baran IJ, Stephens NS. Anthropogenic trauma is the most prevalent cause of mortality in little penguins, Eudyptula minor, in Perth, Western Australia. Emu. 2016;116:52-61.

36. Haman $\mathrm{KH}$, Norton TM, Ronconi RA, Nemeth NM, Thomas AC, Courchesne SJ, et al. Great shearwater (Puffinus gravis) mortality events along the eastern coast of the United States. J Wildl Dis. 2013:49:235-45.

37. Northridge SP. Driftnet fisheries and their impacts on non-target species: a worldwide review. FAO fisheries technical paper. No.320. Rome: FAO; 1991.

38. Fiedler FN, Sales G, Giffoni BB, Monteiro-Filho EL, Secchi ER, Bugoni L. Driftnet fishery threats sea turtles in the Atlantic Ocean. Biodivers Conserv. 2012;21:915-31.

39. Fishing Gear types. Drift gillnets. Technology Fact Sheets. In: FAO Fisheries and Aquaculture Department [online]. Rome. Updated 13 September 2001. http://www.fao.org/fishery/. Accessed 16 Feb 2019.

40. Lord SR, Davis PR. Drowning, near drowning and immersion syndrome. J R Army Med Corps. 2005;151:250-5.

41. Leth PM, Madsen BH. Drowning investigated by post mortem computed tomography and autopsy. J Forensic Radiol Imaging. 2017;9:28-30.

42. Lunetta P, Modell JH. Macroscopical, microscopical, and laboratory findings in drowning victims. In: Tsokos M, editor. Forensic pathology reviews. New York: Humana Press; 2005. p. 3-77.

43. Simpson VR, Fisher DN. A description of the gross pathology of drowning and other causes of mortality in seabirds. BMC Vet Res. 2017:13:302.

44. Jin F, Li C. Seawater-drowning-induced acute lung injury: from molecular mechanisms to potential treatments. J Exp Ther Med. 2017:13:2591-8.

45. Møller AP, Erritzøe J. Host immune defence and migration in birds. Evol Ecol. 1998;12:945-53.

46. García-Borboroglu P, Boersma PD, Ruoppolo V, Reyes L, Rebstock GA, Griot $\mathrm{K}$, et al. Chronic oil pollution harms Magellanic penguins in the Southwest Atlantic. Mar Pollut Bull. 2006;52:193-8.

47. Baldassin P, Taniguchi S, Gallo H, Silva RJ, Montone RC. Persistent organic pollutants in juvenile Magellan penguins (Spheniscus magellanicus) found 
on the northern shore of the state of São Paulo and southern shore of the state of Rio de Janeiro, Brazil. Mar Pollut Bull. 2012;64:2502-6.

48. Silva-Filho RP, Ruoppolo V. Sphenisciformes (Pinguim). In: Cubas ZS, Silva JCR, Catão-Dias JL, editors. Tratado de Animais Selvagens - Medicina Veterinária. São Paulo: Roca; 2014. p. 384-416.

49. Kim CH. Homeostatic and pathogenic extramedullary hematopoiesis. J Blood Med. 2010;1:13-9.

50. Emmons R, Niemiro GM, Owolabi O, De Lisio M. Acute exercise mobilizes hematopoietic stem and progenitor cells and alters the mesenchymal stromal cell secretome. J Appl Physiol. 2016;120:624-32.

51. Obendorf DL, McColl K. Mortality in little penguin (Eudyptula minor) along the coast of Victoria, Australia. J Wildl Dis. 1980;16:251-9.

52. Garbin LE, Navone GT, Diaz Jl, Cremonte F. Further study of Contracaecum pelagicum (Nematoda: Anisakidae) in Spheniscus magellanicus (Aves: Spheniscidae) from Argentinean coasts. J Parasitol. 2007:93:143-50.

53. Yáñez F, Fernández I, Campos W, Mansilla M, Valenzuela A, González H, et al. First pathological report of parasitic gastric ulceration in Humboldt penguin (Spheniscus humboldti) along the coast of south Central Chile. Lat Am J Aquat Res. 2012;40:448-52.

54. Borgsteede FHM. The effect of parasites on wildlife. Vet Q. 1996;3:138-40.

55. Brandão ML, Braga KM, Luque JL. Marine debris ingestion by Magellanic penguins, Spheniscus magellanicus (Aves: Sphenisciformes), from the Brazilian coastal zone. Mar Pollut Bull. 2011;62:2246-9.

56. Pinto MBLC, Siciliano S, Beneditto APM. Stomach contents of the Magellanic penguin Spheniscus magellanicus from the northern distribution limit on the Atlantic coast of Brazil. Mar Ornithol. 2007:35:77-8.

57. Mäder A, Sander M, Casa G Jr. Ciclo sazonal de mortalidade do pinguim-deMagalhães, Spheniscus magellanicus influenciado por fatores antrópicos e climáticos na costa do Rio Grande do Sul, Brasil. Rev Bras Ornitol. 2010;18: 228-33.

58. Tourinho PS. Do Sul JAl, Fillmann G. is marine debris ingestion still a problem for the coastal marine biota of southern Brazil? Mar Pollut Bull. 2010:60:396-401

59. Di Beneditto APM, Dos Santos RA, Rosa KR, Siciliano S. Magellanic penguins: stomach contents and isotopic profiles to assess the feeding demands of juveniles in a wintering area off Brazil. J Mar Biol Assoc UK. 2015;95:423-30.

60. Di Beneditto APM, Siciliano S. Marine debris boost in juvenile Magellanic penguins stranded in south-eastern Brazil in less than a decade: insights into feeding habits and habitat use. Mar Pollut Bull. 2017;125:330-3.

61. García-Borboroglu P, Boersma PD, Ruoppolo V, Pinho-da-Silva-Filho R, Corrado-Adornes A, Conte-Sena D, et al. Magellanic penguin mortality in 2008 along the SW Atlantic coast. Mar Pollut Bull. 2010;60:1652-7.

62. Lewison R, Oro D, Godley BJ, Underhill L, Bearhop S, Wilson RP, et al. Research priorities for seabirds: improving conservation and management in the 21st century. Endanger Species Res. 2012;17:93-121.

63. Eberhart-Phillips LJ, Küpper C, Miller TE, Cruz-López M, Maher KH, Dos Remedios $\mathrm{N}$, et al. Sex-specific early survival drives adult sex ratio bias in snowy plovers and impacts mating system and population growth. Proc Natl Acad Sci U S A. 2017;114:E5474-81.

64. Hocken AG. Post-mortem examination of penquins. DOC science internal series 65. Wellington: New Zealand Department of Conservation; 2002.

65. Rae MA. Practical avian necropsy. Semin Avian Exot Pet Med. 2003;12:62-70.

66. Williams TD. The penguins: Spheniscidae. New York: Oxford University Press; 1995.

67. Andrade CM. Meios e Soluções Comumente Empregados em Laboratórios. Rio de Janeiro: Editora Universidade Rural; 2000.

68. Hoberg EP. Keys to the genera and subgenenera of the family Tetrabothriidae. In: Khalil LF, Jones A, Bray RA, editors. Key to the Cestode parasite of vertebrates. Albans: CAB International; 1994. p. 295-307.

69. Gibson D, Jones A, Bray R. Keys to the Trematoda. London: CAB International; 2002

70. Diaz Jl, Cremonte F, Navone GT. Helminths of the Magellanic penguin, Spheniscus magellanicus (Sphenisciformes), during the breeding season in Patagonian coast, Chubut, Argentina. Comp Parasitol. 2010;77:172-7.

71. Bush A, Lafferty K, Lotz J, Shostak A. Parasitology meets ecology on its own terms: Margolis et al. revisited. J Parasitol. 1997;83:575-83.

\section{Publisher's Note}

Springer Nature remains neutral with regard to jurisdictional claims in published maps and institutional affiliations.

\section{Ready to submit your research? Choose BMC and benefit from:}

- fast, convenient online submission

- thorough peer review by experienced researchers in your field

- rapid publication on acceptance

- support for research data, including large and complex data types

- gold Open Access which fosters wider collaboration and increased citations

- maximum visibility for your research: over $100 \mathrm{M}$ website views per year

At $\mathrm{BMC}$, research is always in progress.

Learn more biomedcentral.com/submissions 